\title{
SISTEM INFORMASI PENGAMANAN SKCK MENGGUNAKAN BARCODE PADA DIT INTELKAM POLDA RIAU
}

\author{
Eki Saputra ${ }^{1}$, Desi Fitri ${ }^{2}$ \\ Program Studi Sistem Informasi Fakultas Sains dan Teknologi \\ Universitas Islam Negeri Sultan Syarif Kasum Riau \\ Jl.HR. Soebrantas No.155 Simpang Baru, Tampan, Pekanbaru, Riau-Indonesia 28293 e- \\ mail: ${ }^{1}$ eki.saputra@uin-suska.ac.id ${ }^{2}$ desifitri0303@gmail.com
}

\begin{abstract}
ABSTRAK
Dit Intelkam Polda Riau menyelenggarakan fungsi untuk memberikan pelayanan kepada masyarakat yaitu pelayanan pengurusan Surat Keterangan Catatan Kepolisian (SKCK). Pengurusan SKCK ini dilakukan dengan mendatangi langsung kantor Dit Intelkam Polda Riau. Proses pembuatan SKCK pada Dit Intelkam Polda Riau, saat ini telah menggunakan database dalam penyimpanan datanya. Namun kelemahannya yaitu data lama pemohon akan hilang apabila belum dilakukannya perpanjangan oleh pemohon sebelum masa berlakunya habis. Hal ini disebabkan karena data lama yang tertimpa oleh data baru yang di-input-kan ke database.Selain itu SKCK yang lama juga tidak mempunyai sistem keamanan sehingga data SKCK tersebut dapat disalahgunakan oleh pihak yang tidak bertanggung jawab. Permohonan penerbitan SKCK pada Dit Intelkam Polda Riau bisa mencapai 200 penerbitan perharinya dengan kategori high section yaitu jumlah bagian dengan penerbitan tertinggi dalam satu hari. Sedangkan untuk pengurusan dalam pertahun dari Tahun 2016 pengurusan bisa mencapai sebanyak 30.000 lembar.Sistem ini menggunakan keamanan barcode, dimana barcode tersebut mempunyai informasi didalamnya yaitu: nama, nomor NIK, tujuan dan masa berlaku SKCK. Metode pengembangan yang digunakan dalam penelitian ini yaitu System Development Life Cycle Model Waterfall yang menggunakan tiga buah diagram Unified Modeling Language (UML), yaitu: usecasediagram, activity diagram dan sequence diagramserta memanfaatkan penggunaan ERD dalam pembuatan database. Pembangunan sistem dilakukan menggunakan beberapa aplikasi pendukung yaitu: PHP dan MySQL,Sublime Text 3, Javascript, dan HTML.Hasil dari penelitian ini dapat memberikan keamanan terhadap data SKCK pemohon dan dapat mempermudah Admin Kepolisian Daerah dalam proses pembuatan surat SKCK.

Kata Kunci: Barcode, Dit Intelkam Polda Riau,Keamanan, SKCK, Unified Modeling Language (UML).

\section{A. PENDAHULUAN}

Kepolisian Negara Republik Indonesia (POLRI) adalah salah satu institusi pemerintah yang bertugas sebagai ujung tombak penegakan hukum di Indonesia. Institusi Polri mempunyai tugas pokok sebagai pemelihara keamanan, ketertiban masyarakat, serta penegakan hukum untuk memberi perlindungan, pengayoman dan pelayanan kepada masyarakat dengan menjunjung tinggi hak asasi manusia.

Kepolisian Negara Republik Indonesia (POLRI) tersebar di tiap daerah yang ada di Indonesia, salah satunya yaitu daerah Provinsi Riau. Di Provinsi Riau terdapat Kepolisian daerah (POLDA) yang bernama Polda Riau, pada Polda Riau terdapat tiga jenis layanan kepada masyarakat yaitu lalu lintas, Reskrim, dan Intelkam yang di tugaskan kepada satuan kerja salah satunya yaitu Dit Intelkam Polda Riau.Dit Intelkam Polda Riau menyelenggarakan fungsi untuk memberikan pelayanan kepada masyarakat diantaranya yaitu perizinan pelayanan pengurusan Surat Keterangan Catatan Kepolisian (SKCK). Pengurusan SKCK, ini dilakukan dengan mendatangi langsung kantor Dit intelkam Polda Riau.

Surat Keterangan Catatan Kepolisian (SKCK) adalah surat yang diterbitkan oleh POLRI yang dapat diberikan kepada orang yang belum pernah terlibat dalam tindakan kejahatan. Dalam pembuatanSKCK ada beberapa data pendukung yang membantu dalam pembuatan SKCK seperti Nomor Induk

Kependudukan (NIK), rumus sidik jari, dan nomor Kartu Keluarga (KK). Berdasarkan hasil wawancara Bamin Giatmas Polda Riau bahwa permohonan penerbitan SKCK pada Dit Intelkam Polda Riau bisa mencapai 200 penerbitan perharinya. Sedangkan dalam pertahun dari Tahun 2016 pengurusan SKCK mencapai sebanyak 30.000 lembar.Ketika melakukan pembuatan SKCK, masyarakat mempersiapkan persyaratan pengurusan SKCK yang dilakukan. Namun dalam pembuatan SKCK, masyarakat terlebih dahulu mengambil sidik jari dan catatan rekomendasi diluar kantor Polda Riau, setelah itu petugas memeriksa persyaratan formulir yang diberikan oleh pemohon, kemudian pemohon mengisi formulir yang diberi oleh petugas, setelah itu petugas akan memeriksa apakah berkas yang diberikan oleh pemohon memenuhi syarat SKCK atau tidak, setelah itu petugas mencetak surat SKCK dan menyerahkannya ke admin untuk diberikan
\end{abstract}


Jurnal Ilmiah Rekayasa dan Manajemen Sistem Informasi, Vol. 5, No. 1, Februari 2019, Hal. 1-7

e-ISSN 2502-8995 p-ISSN 2460-8181

tanda tangan dan cap kemudian pemohon mendapatkan surat SKCK tersebut.

Proses pembuatan SKCK pada Dit Intelkam Polda Riau, saat ini telah menggunakan database dalam penyimpanan datanya. Namun kelemahannya yaitu data lama pemohon akan hilang apabila belum dilakukannya perpanjangan oleh pemohon sebelum masa berlakunya habis. Hal ini disebabkan karena data lama yang tertimpa oleh data baru yang di-input-kan ke database.Selain itu SKCK yang lama juga tidak mempunyai sistem keamanan sehingga data SKCK tersebut dapat disalah gunakan oleh pihak yang tidak bertanggung jawab.

Oleh karena itu, Dit Intelkam Polda Riau membutuhkan sistem informasi keamanan SKCK yang berfungsi untuk menghindari adanya kecurangan atau penyalahgunaan data SKCK. Sistem ini nantinya akan menggunakan keamanan barcode, dimana barcode tersebut mempunyai informasi didalamnya yaitu: nama, nomor NIK, tujuan dan masa berlaku SKCK. Dengan adanya keamanan barcode ini diharapkan tidak ada lagi penyalahgunaanSKCK dan dapat menunjang kerja para staff pada bagian pembuatan SKCK di Dit Intelkam Polda Riau dalam melakukan permohonan pembuatan maupun perpanjangan SKCK, serta untuk mendukung kemajuan pelayanan yang terpadu, sehingga pemohon mendapatkan pelayanan yang lebih cepat dari pada yang sebelumnya.

Penelitian yang serupa telah dilakukan oleh Hendrajati pada Tahun 2013 dengan judul Rekayasa Perangkat Lunak Sentra Pelayanan Kepolisian Terpadu (SPKT) Pada Polrestabes Semarang, penelitian ini dapat membantu dalam meningkatkan pelayanan terhadap laporan masyarakat kepada kepolisian. Selain itu, dengan adanya perangkat lunak SPKT dapat membantu kepolisian dalam proses penyimpanan surat seperti Laporan Kepolisian, Laporan Kehilangan, Laporan Ijin Keramaian, Laporan Pemberitahuan dan SKCK. Selain itu penelitian juga pernah dilakukan oleh Susiloatmadja, dkk pada Tahun 2010 dengan judul Sistem Informasi Pembuatan SKCK Dengan Pemodelan UML, dengan hasil uji coba yaitu: (1) sistem ini terhubung dengan database kriminalitas. (2) sistem ini dapat menyimpan seluruh data pembuatan SKCK yang terjadi setiap hari, baik pembuatan SKCK baru, maupun perpanjangan masa berlaku SKCK. (3) selain itu sistem ini dapat digunakan untuk pembuatan laporan adanya pembuatan SKCK dalam periode bulanan.

Berdasarkan latar belakang tersebut, maka dapat diambil topik penelitian penulisan laporan tugas akhir dengan judul: "Sistem Informasi Keamanan Menggunakan Barcode Pada DIT INTELKAM POLDA RIAU".

\section{B. LANDASAN TEORI}

B.1 Sentra Pelayanan Kepolisian Terpadu (SPKT)

SPKT bertugas memberikan pelayanan kepolisian kepada masyarakat, dalam bentuk penerimaan dan penanganan pertama laporan/pengaduan, pelayanan bantuan/pertolongan kepolisian, bersama fungsi terkait mendatangi TKP untuk melaksanakan kegiatan pengamanan dan olah TKP sesuai ketentuan hukum dan peraturan yang berlaku ${ }^{[1]}$.

\section{B.2 Surat Keterangan Catatan Kepolisian (SKCK)}

Surat Keterangan Catatan Kepolisian yang selanjutnya disingkat SKCK adalah surat keterangan resmi yang dikeluarkan oleh Polri kepada seorang/pemohon warga masyarakat untuk memenuhi permohonan dari yang bersangkutan atau suatu keperluan karena adanya ketentuan yang mempersyaratkan, berdasarkan hasil penelitian biodata dan catatan kepolisian yang ada tentang orang tersebut $^{[2]}$. SKCK merupakan surat yang berisikan akan catatan-catatan dari seseorang terhadap riwayat dirinya atau di khususkan dalam tindak kriminal. Surat Keterangan Catatan Kepolisian (SKCK), dulunya dikenal sebagai Surat Keterangan Kelakuan Baik (SKKB).

\section{B.3 Barcode}

Barcode atau kode batang adalah sekumpulan data yang digambarkan dengan garis dan jarak spasi (ruang). Barcode menggunakan urutan garis batang vertikal dan jarak antar garis untuk mewakili angka atau simbol lainnya. Dengan demikian, setiap ketebalan garis batang dan jarak antara garis saru dengan yang lain selalu berbeda sesuai dengan isi data yang dikandung oleh kode batang atau barcode tersebut ${ }^{[3]}$.

\section{B.4 Object Oriented Analysis Design (OOAD)}

OOAD merupakan sebuah pendekatan untuk memikirkan suatu masalah dengan menggunakan model yang dibuat menurut konsep sekitar dunia nyata. Dasar pembuatannya adalah objek yang merupakan kombinasi antara struktur dasar dan perilaku dalam satu entitas. OOAD mencakup analisis dan desain sebuah sistem dengan pendekatan objek, yaitu analisis berorientasi objek (OOA) dan desain berorientasi objek (OOD). OOA adalah metode analisis yang memeriksa requirement

(syarat/keperluan yang harus dipenuhi sebuah sistem) dari sudut pandang kelas-kelas dan objek-objek yang ditemui dalam lingkungan organisasi. Sedangkan OOD adalah metode untuk mengarahkan arsitektur software yang didasarkan pada manipulasi objekobjek sistem atau sub-sistem ${ }^{[4]}$.

\section{B.5 Unified Modelling Language (UML)}

Unified Modelling Language (UML) adalah sebuah standar bahasa yang banyak digunakan di dunia industri untuk mendefinisikan requirement, membuat 
analisis dan desain, serta menggambarkan arsitektur dalam pemrograman berorientasi objek ${ }^{[5]}$.

\section{B.6 Model Waterfall}

Model SDLC air terjun (waterfall) sering juga disebut model sekuensi linier (sequenntial linear) atau alur hidup klasik (classic life cycle). Model air terjun menyediakann pendekatan alur hidup perangkat lunak secara sekuensial atau terurut dimulai dari analisis, desain, pengodean, pengujian, dan tahap pendukung (support $)^{[6]}$.

\section{Metodologi Penelitian}

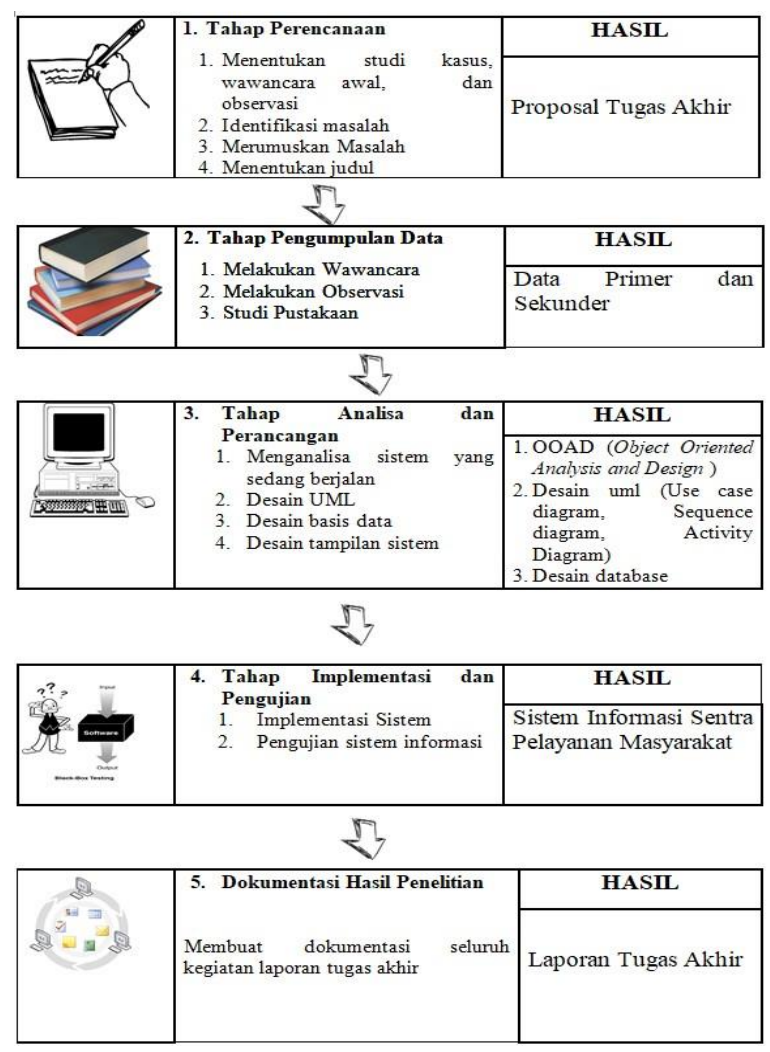

Dibawah ini adalah keterangan dari metodologi penelitian, yaitu:

\section{C.1 Tahap Perencanaan}

Tahap perencanaan adalah tahapan yang harus direncanakan saat akan melakukan penelitian. Adapun tahapan yang direncanakan yaitu:

1. Menentukan Studi Kasus, Wawancara Awal, dan Observasi.

Tahap perencanaan yang pertama dilakukan yaitu menentukan studi kasus penelitian dan telah di tetapkan penelitian akan dilakukan pada Dit Intelkam Polda Riau. Selanjutnya melakukan wawancara awal, wawancara dilakukan dengan Batmin Giatmas. Selanjutnya melakukan observasi mengenai proses sentra pelayanan masyarakat dilakukan pada Dit Intelkam Polda Riau.

2. Identifikasi Masalah

Tahap perencanaan yang kedua yaitu identifikasi masalah melakukan identifikasi masalah-masalah yang selalu terjadi. Identifikasi dilakukan dengan hal-hal yang berhubungan dengan proses sentra pelayanan masyarakat pada Dit Intelkam Polda Riau yang berhubungan dengan sistem yang sedang berjalan.

3. Merumuskan Masalah Tahap perencanaan yang ketiga yaitu merumuskan masalah penelitian telah di dapat apa saja masalah yang terjadi pada Dit Intelkam Polda dan merumuskan masalahnya yaitu bagaimana merancang dan membangun sistem infomasi sentra pelayanan masyarakat pada Dit Intelkam Polda Riau.

4. Menentukan Judul

Tahap perencanaan yang keempat yaitu menentukan judul penelitian setelah didapat masalah penelitian maka didapat judul penelitian yaitu rancang bangun sistem infomasi sentra pelayanan masyarakat pada Dit Intelkam Polda Riau.

\section{C.2 Tahap Pengumpulan Data}

Pada tahap ini dilakukan pengumpulan data untuk lebih mengetahui mengenai permasalahan yang diteliti. Dari data yang dikumpulkan akan dapat diketahui mengenai proses pembelajaran yang terjadi pada saat ini. Data-data dapat diperoleh melalui wawancara langsung dan dengan cara melihat langsung dilapangan proses pembelajaran yang terjadi. Dalam hal ini objek penelitian adalah Dit Intelkam Polda Riau. Hal yang dilakukan untuk mendapatkan data yang dibutuhkan dalam penelitian ini adalah:

1. Wawancara

Dalam penelitian ini penulis menggunakan metode pengumpulan data wawancara tidak terstruktur. Peneliti bertatap muka langsung dengan beberapanarasumberyaituBapak Reggi Chandra Dewa sebagai Bamin Giatmas. Peneliti mengajukan pertanyaan-pertanyaan secara langsung seperti bagaimana prosedur pengurusan SKCK tersebut, apakah pernah terjadi penyalahgunaan, serta adakah permasalahan dalam pengurusan SKCK. Wawancara ini bertujuan untuk mengetahui lebih jelas permasalahan yang terjadi dalamproses layanan masyarakatpada Dit Intelkam Polda Riau.

2. Observasi

Meneliti profil organisasi yang membahas tentang, visi, misi, dan tujuan yang akan menjadi dasar untuk proses analisa dan menemukan solusi dari 
permasalahan yang terjadi saat proses sentra pelayanan masyarakat pada Dit Intelkam Polda Riau. Melihat serta meneliti proses pelayanan masyarakat yang berjalan pada Dit Intelkam Polda Riau.

\section{Studi Literatur}

Menggunakan literatur yang telah ada seperti jurnal-jurnal pendukung dan buku untuk digunakan sebagai referensi atau bahkan digunakan sebagai bahan pembanding. Contoh jurnal yang diambil yakni "Sistem Informasi Data Surat Keterangan Catatan Kepolisian (SKCK)" yang di susun oleh Abdul Ghozi Almustadzichin pada Tahun 2009. Contoh buku yang diambil salah satunya adalah "Rekayasa Perangkat Lunak" yang dikarang oleh Janner Simarmata pada Tahun 2010.

\section{C.3 Tahap Analisa dan Perancangan}

Tahap analisa dan perancangan merupakan tahap ketiga dalam mengerjakan laporan tugas akhir yang mana ada beberapa tahap yang akan di kerjakan mulai dari yang pertama Menganalisa sistem yang sedang berjalan, kedua desain sistem yang akan dibangun, ketiga desain UML, keempat desain basis data, kelima desain tampilan sistem. Adapun penjelasannya sebagai berikut:

1. Menganalisa Sistem yang Sedang Berjalan Tahap analisa dan perancangan yang pertama yaitu menganalisa sistem yang sedang berjalan menganalisa seluruh kegiatan yang dilakukan dalam proses sentra pelayanan masyarakat dengan menggunakan metode pengembangan WaterfalldanObject Oriented Analysis Design (OOAD).

2. Desain UML

Tahap analisa dan perancangan yang kedua yaitu merancang UML dengan tools yang digunakan dalam UML yaitu use case diagram, sequence diagram, dan activity diagram.

3. Desain ERD

Tahap analisa dan perancagan yang ketiga yaitu perancangan yang dibutuhkan pada database. 4 . Desain Tampilan Sistem

Tahap analisa dan perancangan yang keempat yaitu merancang tampilan sistem melakukan perancangan tampilan antarmuka yang akan dibangun.

\section{C.4 Tahap Implementasi dan Pengujian}

Tahapan ini di lakukan dengan tujuan untuk menjamin sistem yang dibuat sesuai dengan hasil analisis dan perancangan serta menghasilkan satu kesimpulan apakah sistem tersebut sesuai dengan yang di harapkan. C.4.1 Implementasi Sistem
Tahap
Implementasi
merupakan
pembangunan

tahap dimana sentra pelayanan mulai dilaksanakan. Pembangunan sistem dilakukan menggunakan beberapa aplikasi pendukung yaitu: PHP dan MySQL,Sublime Text 3, Javascript, dan HTML.

\section{C.4.2 Pengujian Sistem}

Pada tahap ini, sistem yang telah selesai dibangun akan di uji coba. Tujuannya ialah untuk menjamin sistem yang dibangun sesuai dengan hasil yang diharapkan. Pengujian sistem dilakukan dengan metode blackbox, yaitu: proses uji sistem ditampilkan dalam bentuk tabel yang didalamnya menjelaskan tentang deskripsi pengujian, kondisi awal, prosedur pengujian, data input yang digunakan, output yang diharapkan, kriteria evaluasi hasil, hasil yang didapat dan kesimpulan pengujian.

\section{ANalisa dan Perancangan D.1 Analisa Sistem Lama}

Proses sistem yang berjalan dalam pelayanan kegiatan di Dit Intelkam Polda Riau menjadi pelayanan Surat Keterangan Catatan Kepolisian (SKCK) dan Izin Keramaian. Pada pelayanan SKCK sistem yang berlangsung selama ini di mulai dari pemohon melengkapi persyaratan yang ditentukan oleh pihak Dit Intelkam yaitu berupa fotocopy Kartu Tanda Penduduk (KTP) dan Kartu Keluarga (KK), sidik jari dan rekom catatan kriminal, pas foto warna latar merah 4x6 sejumlah 4 lembar dan mengisi formulir. Persyaratan tersebut lalu di teliti oleh pihak petugas pelayanan Dit Intelkam Polda Riau, kemudian dilakukan proses pada berkas SKCK, lalu pihak petugas pelayanan menyerahkan SKCK kepada pemohon. Keseluruhan pelayanan kegiatan oleh pihak Dit Intelkam Polda Riau mengharuskan pihak pemohon mendatangi langsung kantor Dit Intelkam Polda Riau. Selanjutnya pihak pemohon melengkapi ketentuan-ketentuan yang di tetapkan oleh Dit Intelkam Polda Riau dan jika sesuai sebagaimana mestinya pihak pelayanan kegiatan merealisasikan maksud atau kehendak dari pihak pemohon. Sistem seperti ini tentunya belum dikatakan efektif dan efesien dan akan jauh lebih mudah jika pihak pemohon bisa menyampaikan aspirasi atau kehendaknya melalui jalur khusus dalam bentuk website. Berikut adalah Alur proses sistem lama yang dapat dilihat pada Gambar 4.1 :

Alur kerja pada penelitian ini dapat dilihat pada Gambar 4.1.

\section{D.2 Analisa Permasalahan}

Pada tahap ini dilakukan identifikasi permasalahan yang terdapat pada proses yang sedang berjalan saat ini di Dit Intelkam Polda Riau. Masalah inilah nantinya yang akan diuraikan dengan usulan sistem yang baru. 
Berdasarkan wawancara dan observasi, dapat disimpulkan permasalahan sentra pelayanan masyarakat yang terdapat pada Dit Intelkam Polda Riau adalah sebagai berikut:

1. Beberapa kasus mengenai masyarakat diluar daerah atau diluar provinsi Riau masih menggunakan KTP diluar daerah provinsi riau.

2. Administasinya belum lengkap, perbedaan Nomor Induk Kependudukan (NIK) didalam Kartu Keluarga (KK) dan didalam KTP, sehingga Polda Riau tidak bisa menginput data sebelum ada surat keterangan bahwasanya yang dipakai adalah NIK didalam KTP atau NIK yang ada didalam KK.

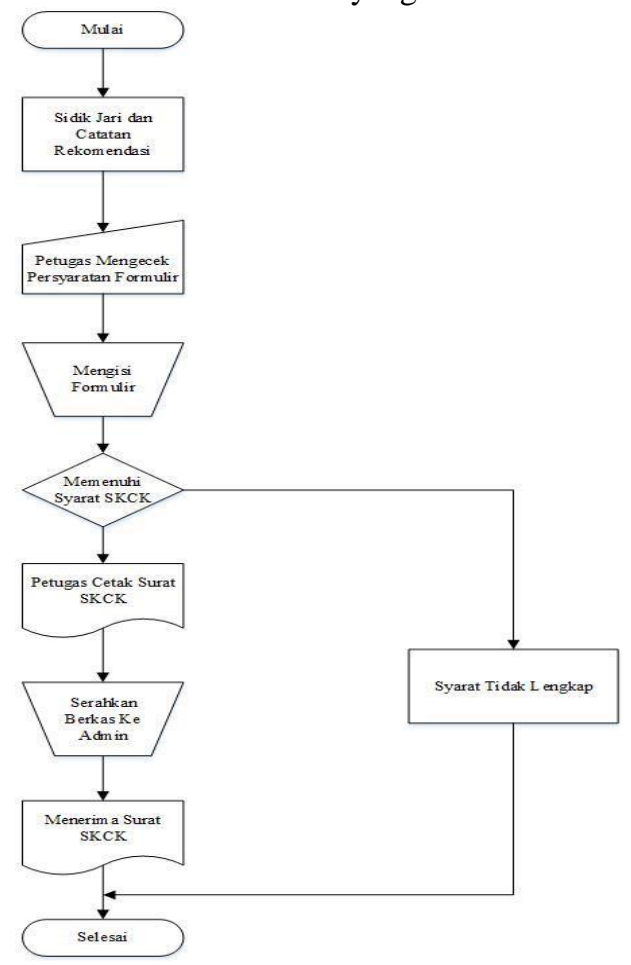

Gambar 4.1. Flowchat Proses Sistem Lama

3. Pengurusan SKCK dalam perharinya mencapai 130 high season, low season 80 rata-rata perharinya sehingga memerlukanwaktu yang banyakbagi admin dan staf untukmerekap kembalisatupersatu data masyarakat tersebutkedalam word untukdimasukan ke database.

4. Sering terjadinya permasalahan jaringan pada jaringan internet tersebut sehingga menyulitkan petugas untuk memasukan data masyarakat ke database.

5. Masyarakat banyak tidak paham bagaimana tata cara mengurus surat izin keramaian.

\section{D.3 Analisa Sistem Usulan}

Dalam sistem yang diusulkan ini ada perubahan yang dilakukan, yaitu pada proses pertama pemohon melakukan registrasi akun sistem. Kemudian pemohon langsung bisa membuat akun baru, kemudian pemohon login untuk masuk ke sistem. Kemudian pemohon mengisi data diri akan masuk kedalam database untuk memenuhi persyaratan registrasi SKCK. Selanjutnya admin bisa lansung melakukan validasi secara keseluruhan. Setelah validasi admin melakukan print untuk mencetak surat SKCK. Setalah itu admin melakukan rekapitulasi laporan, laporan tersebut akan dikirim ke pimpinan untuk dapat mengecek laporan.

Sistem usulan akan dirancang adalah sistem informasi berbasis web, menggunakan bahasa pemrograman PHP (Hypertext Preprocessor), dan MySQL sebagai database-nya. Pada perancangan ini mencakup Use Case Diagram, Activity Diagram, dan Sequence Diagram. Selanjutnya akan terlihat seperti dibawah ini: D.3.1 Aktor

Aktor utama adalah pemohon SKCK, petugas pada bagian pembuatan SKCK, serta pimpinan dalam hal ini Kepala Dit Intelkam Polda Riau yang nanti akan menvalidasi SKCK dan Laporan yang terlibat dalam proses surat pengantar merupakan suatu entitas yang berinteraksi dengan sistem untuk melakukan suatu pekerjaan. Adapun aktor yang terlibat didalam sistem ini adalah sebagai berikut :

Pada sistem usulan ini, aktor-aktor yang terlibat langsung dalam penggunaan sistem dapat dilihat pada gambar 4.2.
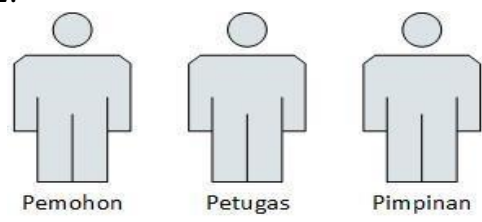

Gambar 4.2 Aktor yang terlibat

Tabel 4.1 Daftar Aktor

\begin{tabular}{|c|l|}
\hline \multicolumn{1}{|c|}{ Aktor } & \multicolumn{1}{|c|}{ Deskripsi } \\
\hline Pemohon & a. Registrasi Acoount \\
& b. Log-In melalui website \\
& c. Registrasi SKCK \\
& d. Registrasi Izin Keramain \\
& e. Daftar SKCK Pemohon \\
& f. Mendapatkan Kode SKCK \\
& g. Menerima surat SKCK \\
\hline
\end{tabular}


Jurnal Ilmiah Rekayasa dan Manajemen Sistem Informasi, Vol. 5, No. 1, Februari 2019, Hal. 1-7 e-ISSN 2502-8995 p-ISSN 2460-8181

\begin{tabular}{|l|l|}
\hline Petugas & a. Melakukan Login \\
& b. Mengkelola SKCK \\
& c. Mengkelola Izin Keramaian \\
& d. Registrasi SKCK \\
& $\begin{array}{l}\text { e. Melakukan pengarsipan } \\
\text { dalam bentuk laporan }\end{array}$ \\
& perbulan \\
\hline Pemimpin & a. Mencetak surat SKCK \\
& $\begin{array}{l}\text { benerima data } \\
\text { bemonmelaluisistem }\end{array}$ \\
& c. Menandatanganisurat SKCK \\
\hline & \multicolumn{2}{|c|}{ sudahditandatanganimelalui fax } \\
\hline & d. Melakukanpengecekanlaporanper \\
& \multicolumn{2}{|c|}{ bulan } \\
\hline
\end{tabular}

\section{D.3.2 Use Case Diagram}

Gambaran sistem secara garis besar fungsi sistem dapat dilihat pada use case diagram yang dapat dilihat pada gambar 4.3 berikut :

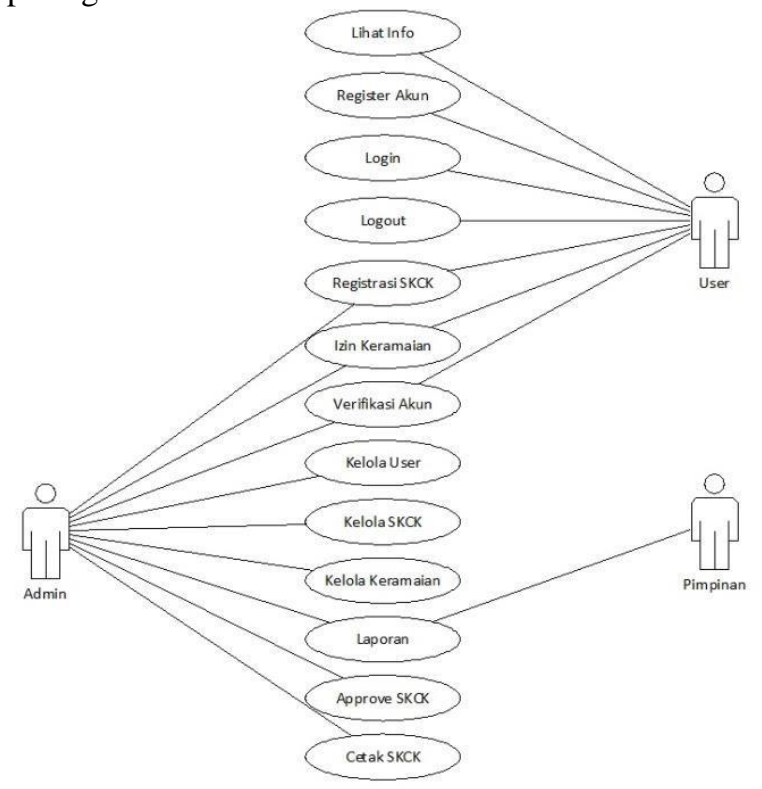

Gambar 4.3 Usecase Diagram

\section{E. IMPLEMENTASI DAN HASIL}

\section{E.1 Tampilan Sistem Informasi Sentra Pelayanan} Masyarakat

a. Tampilan Menu Utama

Tampilan berikut adalah tampilan awal dari sistem informasi sentra pelayanan masyarakat pada Dit Intelkam Polda Riau yang dapat dilihat pada Gambar 5.1 .

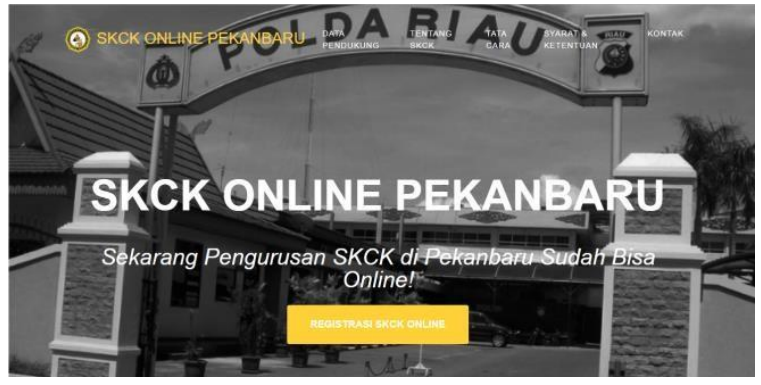

Gambar 5.1 Tampilan Hal Utama

b. Tampilan Halaman Login

Selamat Datang di Sentra Pelayanan Masyarakat Pekanbaru

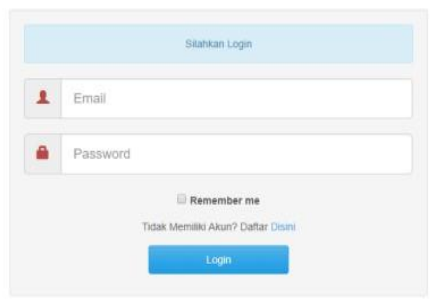

Gambar 5.2: Tampilan Menu Login

c. Tampilan Halaman Registrasi SKCK Pada tampilan halaman registrasi SKCK ini, aktor melakukan pembuatan SKCK melalui sistem dengan mengisi data diri dan kelengkapan data lainnya.

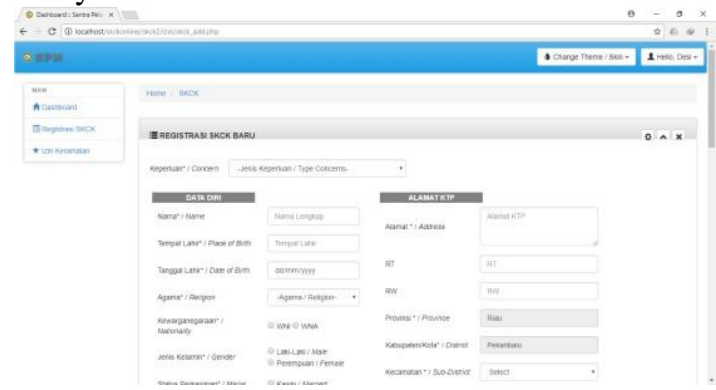

Gambar 5.3: Tampilan Registrasi SKCK

d. Tampilan Halaman Izin Keramaian Pada tampilan halaman izin keramaian ini, aktor melakukan pengisian data sesuai dengan kegiatan yang akan dilakukan oleh pemohon. 


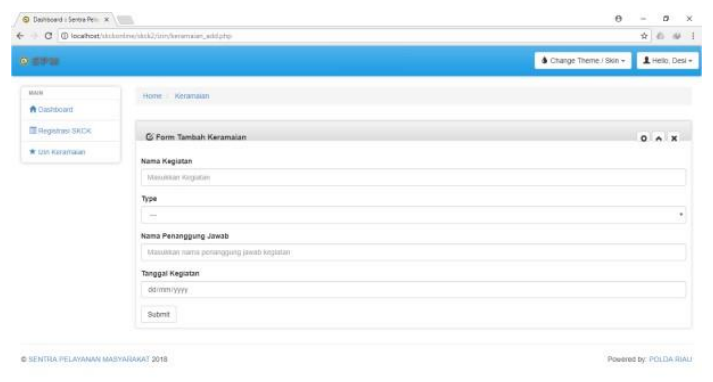

cepat dan dapat mempermudah Admin Kepolisian Daerah dalam proses pembuatan surat SKCK dan Surat Izin Keramaian.

2. Masyarakat merasa terbantu dengan adanya sistem yang memudahkan mereka dalam kepengurusan SKCK dan Surat Izin Keramaian sehingga masyarakat dapat mendapatkan kenyamanan dan menghemat waktu pada saat mengurus surat-surat tersebut.

3. Sistem Ini menghasilkan laporan berupa Surat Keterangan Catatan Kepolisian (SKCK), register SKCK, dan Izin Keramaian berdasarkan bulan dan tahun.

\section{F.2 Saran}

Berdasarkan kesimpulan yang telah disampaikan diatas, maka penulis menyarankan dan merekomendasikan beberapa hal sebagai berikut:

1. Kedepannya sistem informasi ini dapat menampilkan grafik laporan pembuatan

SKCK dan Izin Keramaian seharusnya pihak stakeholder dapat melihat perkembangan pembuatan surat dalam jarak waktu yang diinginkan .

2. Diharapkan sistem informasi ini tidak hanya mengelola SKCK dan Izin keramaian saja, tetapi semua proses surat menyurat yang ada pada Dit Intelkam Polda Riau.

\section{REFERENSI}

[1] Hendrajati , A. (2013). Rekayasa Prangkat Lunak Sentra Pelayanan Kepolisian Terpadu (SPKT) Pada Polrestabes Semarang. Universitas Dian Nuswantoro Semarang 2013, 1-11.

[2] Peraturan Kepala Kepolisian Negara Republik Indonesia Nomor 18 Tahun 2014 tentang Tata Cara Penerbitan Surat Keterangan Catatan Kepolisian. Kepala Kepilisan Negara Republik Indonesia. Jakarta.

[3] Sukrianto, D. (2017). Penerapan Teknologi Barcode Pada Pengolahan Data Pembayaran Sumbangan Pembinaan Pendidikan (SPP). Jurnal Intra-Tech, 1-10.

\section{F. Penutup \\ F.1 Kesimpulan}

Berdasarkan alur penelitian mulai dari analisa, perancangan, implementasi serta pengujian sistem informasi sentra pelayanan masyarakat berbasis web yang telah penulis paparkan pada bab sebelumnya, maka dapat di buat beberapa kesimpulan, yaitu:

1. Setelah merancang dan membangun sistem informasi sentra pelayanan Surat Keterangan Catatan Kepolisian (SKCK) maka kinerja dari staf di bagian Dit Intelkam Riau terbilang cukup 
Jurnal Ilmiah Rekayasa dan Manajemen Sistem Informasi, Vol. 5, No. 1, Februari 2019, Hal. 1-7 e-ISSN 2502-8995 p-ISSN 2460-8181

[4] Nugroho, A. (2005). Analisis dan Perancangan Sistem Informasi Dengan Metodologi Berorientasi Objek . Bandung: Informatika.

[5] Rosa, A. S., \& Shalahuddin, M. (2013). Rekayasa Perangkat Lunak Terstruktur dan Berorientasi Objek. Bandung: Informatika.

[6] Nugroho, A. (2010). Rekayasa Perangkat Lunak. Yogyakarta: ANDI. 